\title{
Kinetic Flow-injection Determination of Hydrogen Peroxide by Use of Iron(III)-catalyzed Coloration and Its Application to the Determination of Biological Substances
}

\author{
Norie MaeuchiHara,* Shigenori NaKano,** and Takuji KaWAShIMA*广 \\ *Laboratory of Analytical Chemistry, Department of Chemistry, University of Tsukuba, \\ Tsukuba 305-8571, Japan \\ **Department of Environmental Sciences, Faculty of Education and Regional Sciences, Tottori University, \\ Tottori 680-0945, Japan
}

\begin{abstract}
A kinetic flow-injection (FI) method is described for the determination of hydrogen peroxide. This method is based on an iron(III)-catalyzed oxidative coupling of 4-aminoantipyrine with $N, N$-dimethylaniline by hydrogen peroxide. By measuring the change in the absorbance of the dye formed at $560 \mathrm{~nm}, 1 \times 10^{-6}-6 \times 10^{-4} \mathrm{M}$ hydrogen peroxide could be determined with a sampling rate of $15 \mathrm{~h}^{-1}$. The relative standard deviation $(n=30)$ was $0.8 \%$ for $5 \times 10^{-5} \mathrm{M}$ hydrogen peroxide. There was little interference of the co-existing ions and compounds. After introducing some immobilized enzyme reactors to the FI system, the proposed method allowed the determination of glucose and uric acid ranging from 1 $\times 10^{-6}$ to $6 \times 10^{-4} \mathrm{M}$ with relative standard deviations of below $2 \%$. The applicability of the method was demonstrated by determining these substances in serum samples.
\end{abstract}

(Received August 7, 2000; Accepted October 11, 2000)

\section{Introduction}

Hydrogen peroxide is widespread at trace levels in natural waters, and plays an important role in natural oxidation

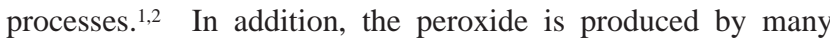
enzymatic reactions through the uptake of oxygen. The need for rapid and simple methods capable of determining trace amounts of the peroxide is increasing in environmental, clinical and food analyses. A number of manual and flow-injection (FI) methods have been reported for the determination of hydrogen peroxide by using enzymatic and nonenzymatic reactions combined with photometric, ${ }^{3-7}$ fluorometric, ${ }^{8-12}$ chemiluminescent ${ }^{13-17}$ and electrochemical ${ }^{18,19}$ detections. Especially, FI procedures including immobilized enzyme reactors, which lead to the generation of hydrogen peroxide, have provided attractive methods for specific determinations of clinically interesting substances, such as glucose, cholesterol and glutamic acid. $5,16,19-26$ Although these methods could determine micro- or submicromolar levels of hydrogen peroxide or biological substances, they suffer from disadvantages due to the use of unstable and/or expensive reagents and of complicated equipment.

The reaction system of 4-aminoantipyrine (AA) with a coupling agent, such as 5-dichloro-2-hydroxybenzenesulfonic acid (DCPS) ${ }^{27}$ and $\mathrm{N}, \mathrm{N}$-dimethylaniline (DMA), ${ }^{21,28}$ was used as an oxygen acceptor for the determination of glucose by detecting hydrogen peroxide produced in the presence of peroxidase as a catalyst. A system of AA-DCPS with iron(II) in place of peroxidase was applied to an FI procedure for

† To whom correspondence should be addressed. 183-23 Minami-nakazuma, Tsukuba 305-0065, Japan (T. K.) E-mail: kawasima@staff.chem.tsukuba.ac.jp determining hydrogen peroxide. ${ }^{7}$ This FI method allowed peroxide determination in the concentration range $0.1-4 \times 10^{-4}$ M. However, the sensitivity of the method is not sufficient. We have reported on the photometric-catalytic methods for determining vanadium(IV, V) based on its catalytic effect on the color-forming reaction of AA with DMA. ${ }^{29-31}$ Iron(III) also catalyzes this coloration in the presence of hydrogen peroxide; this iron(III)-catalyzed reaction has been utilized for the determination of total iron, ${ }^{32}$ but not for hydrogen peroxide.

The present paper describes a photometric FI method for the determination of hydrogen peroxide based on the iron(III)catalyzed oxidative coupling of AA with DMA without peroxidase. Under the opitimum conditions obtained in the proposed FI system, as low as $10^{-6} \mathrm{M}$ hydrogen peroxide could be determined at a sampling frequency of $15 \mathrm{~h}^{-1}$. The selectivity of the method is satisfactory with few interfering ions and compounds. After introducing each enzyme reactor consisting of glucose oxidase and uricase to the FI system, glucose and uric acid were easily determined by detecting hydrogen produced peroxide. The method was successfully applied to the determination of these substrates in standard sera.

\section{Experimental}

\section{Reagents}

All chemicals used were of analytical reagent grade. Deionized water with purified with a Millipore Milli-Q system was used throughout. Working solutions of hydrogen peroxide were prepared by the stepwise dilution of a stock solution, which was standardized by permanganate titration with a $0.2 \mathrm{M}$ acetate buffer ( $\mathrm{pH} 4.6)$.

4-Aminoantipyrine (AA) purchased from Nakarai Kagaku 
Co., Japan, was used without purification. A $4.0 \times 10^{-3} \mathrm{M}$ AA solution was prepared by dissolving $0.203 \mathrm{~g}$ of the compound in $250 \mathrm{ml}$ of acetate buffer. $N, N$-Dimethylaniline (DMA) was obtained from Wako Junyaku Co., Japan, and a $5.0 \times 10^{-3} \mathrm{M}$ DMA solution was prepared by dissolving $0.152 \mathrm{~g}$ of the compound in $250 \mathrm{ml}$ of an acetate buffer solution. An iron(III) solution $\left(1.3 \times 10^{-4} \mathrm{M}\right)$ was prepared by diluting a standard solution of iron(III) (1.0 mg ml-1) obtained from Kanto Kagaku Co., Japan.

For the standard glucose solution $\left(1 \times 10^{-3} \mathrm{M}\right)$, anhydrous $\beta$ D-glucose (Wako Junyaku Co., Japan) was dissolved in water and stood for at least $24 \mathrm{~h}$ before use to ensure the attainment of mutarotation equilibrium. This solution was stable for one week at room temperature. A standard solution of uric acid $(1 \times$ $10^{-3} \mathrm{M}$ ) was prepared by dissolving the compound (Sigma, USA) in water. These working solutions were prepared daily by accurate dilution. Buffer solutions $(0.1 \mathrm{M})$ of $2-(N-$ morpholino)ethanesulfonic acid (MES) and $N$-tris(hydroxymethyl)methyl-3-aminopropanesulfonic acid (TAPS) were also prepared.

Glucose oxidase (GOD, $101 \mathrm{U} \mathrm{mg}^{-1}$ ) and uricase (URC, $5.7 \mathrm{U}$ $\mathrm{mg}^{-1}$ ) were purchased from Toyobo Co., Japan. Controlled-pore glass (CPG) was obtained from Electro-Nucleonics Co., USA in 120 - 200 mesh with pore diameters of $75,170,350,700,1400$ and $3000 \AA$.

Standard sera for the determination of glucose and uric acid (Iatron Laboratories Inc., Japan, American Dade Co., USA and Technicon Instruments Co., USA) were used to evaluate the proposed method.

\section{Preparation of enzyme reactors}

The immobilization of enzymes on CPG was carried out according to the literature. ${ }^{24-26}$ After being cleaned with 5\% nitric acid and water, and dried at $95^{\circ} \mathrm{C}$, the $\mathrm{CPG}$ was then silanized with $5 \mathrm{~g}$ of $10 \%$ (3-aminopropyl)triethylsilane in 45 $\mathrm{ml}$ of acetate buffer solution $\left(\mathrm{pH} \mathrm{3.75)}\right.$ at $75^{\circ} \mathrm{C}$ for $2.5 \mathrm{~h}$. The silanized $\mathrm{CPG}$ was rinsed with water and dried at $95^{\circ} \mathrm{C}$ to allow storage. A portion $(5 \mathrm{~g})$ of $2.5 \%$ glutaraldehyde was added to 1 $\mathrm{g}$ of the silanized CPG. The reaction proceeded for $30 \mathrm{~min}$ under reduced pressure and for $1 \mathrm{~h}$ at room temperature. After the CPG had been rinsed with water, the immobilization of GOD (100 $\mathrm{mg}$ in $3 \mathrm{ml}$ of $0.1 \mathrm{M}$ phosphate buffer at $\mathrm{pH} 7.0$ ), and URC (50 mg in $3 \mathrm{ml}$ of $0.1 \mathrm{M}$ borate buffer at $\mathrm{pH}$ 9) was carried out at $4^{\circ} \mathrm{C}$ for $2.5 \mathrm{~h}$. The enzyme-bound CPGs were packed into a Teflon tube (i.d. $1 \mathrm{~mm}, 10 \mathrm{~mm}$ long) with the ends treated internally to fit the connectors; they were stored at $4^{\circ} \mathrm{C}$ when not in use. These enzyme reactors can be used for at least one month, although the activities of immobilized enzymes decreased to about $70-80 \%$ compared to the initial ones.

\section{Apparatus}

A schematic diagram of the FI system used is shown in Fig. 1. The system was constructed from the following components: two double-plunger micropumps (Sanuki Kogyo DM2M-1026), a six-way injection valve (Sanuki Kogyo SVM-6M2) with a loop, two thermostated baths (Taiyo Kagaku Kogyo, Thermo Minder DX-100), a spectrophotometer (Soma Kogaku S-3250) equipped with a flow cell ( $8 \mu \mathrm{l}$ volume, $10 \mathrm{~mm}$ path length) and a Chino EB22005 recorder. Flow lines were made of PTFE tubings (0.5 mm i.d.) and connectors. A Corning Model 12 $\mathrm{pH} / \mathrm{mV}$ meter was also used for $\mathrm{pH}$ measurements of the waste solutions.

\section{Procedure}

An FI system as shown in Fig. 1, without a reactor column,

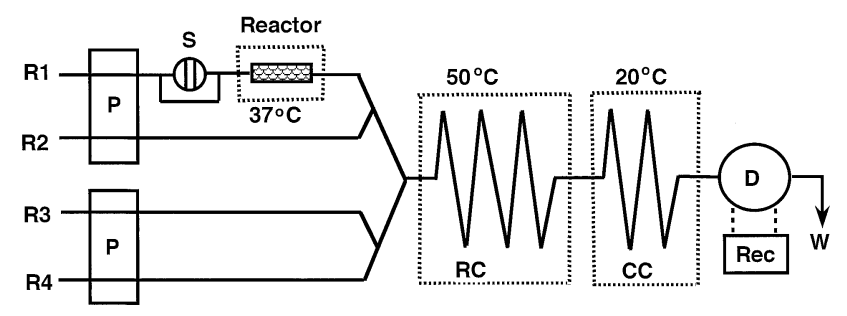

Fig. 1 Flow system for the determination of hydrogen peroxide, glucose and uric acid. $\mathrm{R} 1$, carrier (acetate $(\mathrm{pH}=4.6)$ for $\mathrm{H}_{2} \mathrm{O}_{2}$, MES $(\mathrm{pH}=5.4)$ for glucose, TAPS $(\mathrm{pH}=7.5)$ for uric acid); R2, AA $(4 \times$ $\left.10^{-3} \mathrm{M}\right)$; R3, DMA $\left(5 \times 10^{-3} \mathrm{M}\right)$; R4, Fe(III) $\left(1.3 \times 10^{-4} \mathrm{M}\right)$; P, pump

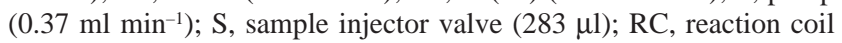
$(2.5 \mathrm{~m})$; CC, cooling coil $(2 \mathrm{~m})$; D, detector $(560 \mathrm{~nm})$; Rec, recorder; $\mathrm{W}$, waste.

was used for the determination of hydrogen peroxide. Carrier (R1, acetate buffer), AA (R2), DMA (R3) and iron(III) (R4) solutions were propelled into the flow lines at a flow rate of $0.37 \mathrm{ml} \mathrm{min} \mathrm{m}^{-1}$, respectively. A $283-\mu \mathrm{l}$ volume of sample solution containing below $1 \times 10^{-4} \mathrm{M}$ hydrogen peroxide was introduced into the carrier flow line by an injection valve, and was then mixed with a solution including AA, DMA and iron(III). The color-forming reaction proceeded in a reaction coil $(2.5 \mathrm{~m})$ immersed in a thermostated bath at $50^{\circ} \mathrm{C}$. The colored solution was passed through the cooling coil $(2 \mathrm{~m})$ at $20^{\circ} \mathrm{C}$, which allowed stabilization of the baseline, and the flowthrough cell. The change in the absorbance was measured at $560 \mathrm{~nm}$ and recorded on a recorder.

For the determination of glucose and uric acid, each enzyme reactor immersed in a thermostated bath at $37^{\circ} \mathrm{C}$ was placed behind the injector valve in the flow system, as shown in Fig. 1. The $\mathrm{pH}$ of buffer solutions used as carriers for glucose and uric acid was 5.4 (MES) and 7.5 (TAPS), respectively. Appropriate amounts of $0.2 \mathrm{M}$ acetic acid were added to the iron(III) solution (R4) in order to adjust the $\mathrm{pH}$ of the stream in the reaction coil to 4.6. A sample solution containing glucose and uric acid was injected into the carrier solution and passed through the reactor column to generate hydrogen peroxide. The generated hydrogen peroxide was reacted with the reagents in the reaction coil and the absorbance change was measured as described above.

\section{Results and Discussion}

In the presence of hydrogen peroxide and iron(III) as a catalyst, AA reacts with DMA to form an intensively colored indamine dye, $\quad N$-(2,3-dimethyl-1-phenyl-5-pyrazolone)- $N^{\prime}, N^{\prime}$-dimethylamino- $p$-benzoquinone diiminonium, as described previously. ${ }^{29-32}$ The absorption maximum of the reaction product was found at around $560 \mathrm{~nm}$. The change in the absorbance was continuously monitored at this wavelength in the FI system.

\section{Optimum conditions for the determination of hydrogen peroxide}

The flow-injection variables, such as sample size, flow rate, reaction coil length, reaction temperature and reagent concentrations, were optimized for the determination of hydrogen peroxide by using a flow system, as shown in Fig. 1, without an enzyme reactor column.

The characteristics of the dispersion $(D)$ of the sample solution were investigated in the sample size range 105-1201 $\mu l$ by injecting a Methyl Orange solution. Higher sample sizes 


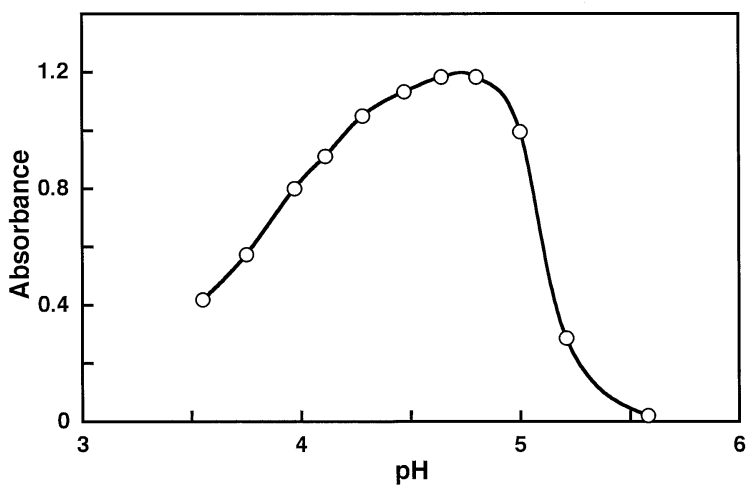

Fig. 2 Effect of the $\mathrm{pH}$ on the peak height by injecting a $1 \times 10^{-3} \mathrm{M}$ hydrogen peroxide solution. $C_{\mathrm{AA}}, 1 \times 10^{-3} \mathrm{M} ; C_{\mathrm{DMA}}, 1 \times 10^{-3} \mathrm{M}$; $C_{\mathrm{Fe}(\mathrm{III})}, 5.4 \times 10^{-5} \mathrm{M}$. All other conditions as in Fig. 1 without a reactor column.

gave a lower dispersion and a slower sampling frequency. A $283 \mu \mathrm{l}$ of sample size $(D=2.3)$ was chosen, taking into account the sensitivity and sampling frequency. The peak height for hydrogen peroxide obviously depended on the flow rate and reaction coil length; a lower flow rate and a longer reaction coils gave higher peaks. To obtain higher sensitivity and sampling frequency, a flow rate of $0.37 \mathrm{ml} \mathrm{min}^{-1}$ in each stream and a $2.5-\mathrm{m}$ reaction coil were selected for the proposed procedure. Figure 2 shows the effect of the $\mathrm{pH}$ on the color development with injection of a $1.0 \times 10^{-3} \mathrm{M}$ hydrogen peroxide solution. The peak height increased with increasing $\mathrm{pH}$. However, the peak height decreased above $\mathrm{pH} 4.8$, probably because of the hydrolysis of iron(III). The reaction was thus carried out at $\mathrm{pH}$ 4.6. The peak height also increased with increasing reaction temperature. At above $60^{\circ} \mathrm{C}$, the peak height was constant, but the reproducibility became poorer. The reaction coil was thus immersed in a thermostated bath at $50^{\circ} \mathrm{C}$.

The effect of the AA and DMA concentrations on the color development was examined at a constant concentration of iron(III) by injecting a hydrogen peroxide solution. The peak heights increased with increasing AA and DMA concentrations, and were then almost constant at the AA concentrations above $3.0 \times 10^{-3} \mathrm{M}$ and at the DMA concentrations above $4.0 \times 10^{-3}$ $\mathrm{M}$, respectively. Concentrations of $4.0 \times 10^{-3} \mathrm{M}$ AA and $5.0 \times$ $10^{-3}$ M DMA were selected for the procedure. Figure 3 shows the effect of the iron(III) concentration on the peak heights by injecting $5.0 \times 10^{-4} \mathrm{M}$ and $1.0 \times 10^{-3} \mathrm{M}$ hydrogen peroxide solutions. An increase in the iron(III) concentration gave higher peaks; then, constant peak heights were obtained at the iron(III) concentrations above $1.1 \times 10^{-4} \mathrm{M}$. A $1.3 \times 10^{-4} \mathrm{M}$ iron(III) concentration was chosen for the procedure.

\section{Calibration graphs for hydrogen peroxide}

Under the conditions optimized for the determination of hydrogen peroxide, linear calibration graphs were obtained in the concentration range $1.0 \times 10^{-6}-6.0 \times 10^{-4} \mathrm{M}$. The detection limit for a signal-to-noise ratio of 2 was $5 \times 10^{-7} \mathrm{M}$. The reproducibility in the peak heights was tested by measuring thirty determinations of a $5.0 \times 10^{-5} \mathrm{M}$ of hydrogen peroxide solution. The relative standard deviation was $0.8 \%$ with a sampling rate of $15 \mathrm{~h}^{-1}$.

\section{Effect of foreign substances}

The effect of foreign ions and compounds on the determination of $1.0 \times 10^{-5} \mathrm{M}$ hydrogen peroxide was examined

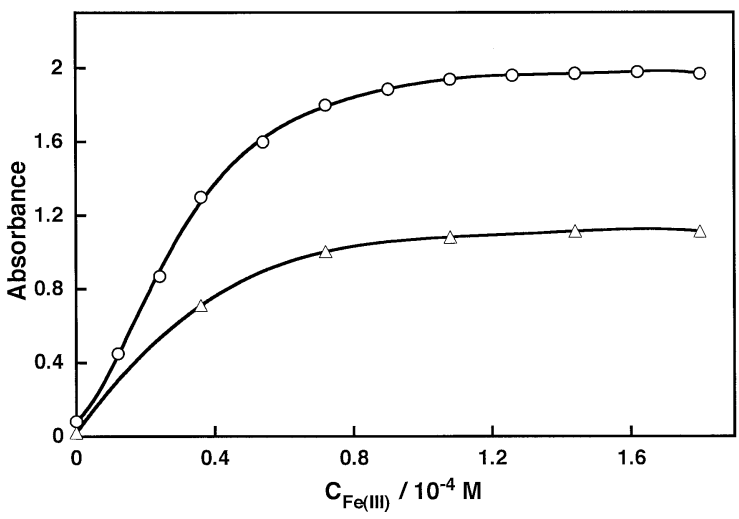

Fig. 3 Effect of iron(III) concentration on the peak height by injecting $5 \times 10^{-4} \mathrm{M}(\triangle)$ and $1 \times 10^{-3} \mathrm{M}(\mathrm{O})$ hydrogen peroxide solutions. All conditions as in Fig. 1 without a reactor column.

over the concentration range $1.0 \times 10^{-5}-1.0 \times 10^{-3} \mathrm{M}$. The results are summarized in Table 1. Copper(II), Mo(VI), Ti(IV) and $\mathrm{W}(\mathrm{VI})$ at a concentration of $1.0 \times 10^{-5} \mathrm{M}$ gave negative errors, probably because of the reaction of these ions with hydrogen peroxide. Phosphate and citrate gave rise to negative errors due to the formation of iron(III)-complexes. Albumin at a concentration of $0.5 \mathrm{~g} \mathrm{ml}^{-1}$ gave a negative error, but $0.2 \mathrm{~g}$ $\mathrm{ml}^{-1}$ of albumin did not interfere. Therefore, hydrogen peroxide can be determined by the dilution of sample solutions to avoid interference from these substances.

\section{Applications to the determination of glucose and uric acid}

In order to apply the present method to the determinations of glucose and uric acid in standard sera by using reactor columns consisting of enzyme-bound CPGs, the enzymatic reaction variables, such as pore diameter of $\mathrm{CPG}$, reactor temperature and $\mathrm{pH}$ of the carrier solution, were optimized.

After glucose oxidase (GOD) and uricase (URC) were immobilized on CPGs having different pore diameters over the range $75-3000 \AA$, the effect of the pore diameter of CPG on the peak heights was examined by injecting glucose $\left(5 \times 10^{-5}\right.$ $\mathrm{M})$ and uric acid $\left(1 \times 10^{-5} \mathrm{M}\right)$, because the pore diameter seemed to affect the degree of immobilization of each oxidase and the rate of reaction with substrates. The maximum peak heights for GOD and URC were obtained at pore diameters of 170 and $1400 \AA$, respectively. Thus, CPGs having these pore diameters were used as the enzyme supporters.

The effect of the reactor temperature on the efficiency of these immobilized oxidase was evaluated in the range $25-70^{\circ} \mathrm{C}$. The peak heights remained constant at temperatures ranging 25 $40^{\circ} \mathrm{C}$ for GOD and URC. The thermal stability of these reactors was also examined; they were stable in the range $25-40^{\circ} \mathrm{C}$. At temperatures above $45^{\circ} \mathrm{C}$, the peak heights gradually decreased. Therefore, the enzyme reactors were maintained at $37^{\circ} \mathrm{C}$. The effect of the carrier $\mathrm{pH}$ on the activity of these enzymes was investigated in the range $5-9.8$ by using MES and TAPS as buffer agents instead of acetate. The GOD activity was not affected by the $\mathrm{pH}$ in the range 5.0-9.8. The maximum activitiy of URC was observed at $\mathrm{pH}$ 7.5. For the determination of glucose and uric acid, buffer solutions at pH 5.4 (MES) and 7.5 (TAPS) were used as carriers. Then, the $\mathrm{pH}$ of the stream in the reaction coil was adjusted to 4.6 by adding appropriate amounts of acetic acid to the iron(III) solution (R4), because the iron(III)-catalyzed reaction proceeded at this $\mathrm{pH}$, as described above. 
Table 1 Effect of foreign ions and compounds on the determination of $1 \times 10^{-5} \mathrm{M}$ hydrogen peroxide

\begin{tabular}{|c|c|c|c|c|c|}
\hline $\begin{array}{l}\text { Ion or } \\
\text { compound }\end{array}$ & Conc./M & $\begin{array}{c}\text { Relative } \\
\text { peak height }\end{array}$ & $\begin{array}{c}\text { Ion or } \\
\text { compound }\end{array}$ & Conc./M & $\begin{array}{l}\text { Relative } \\
\text { peak height }\end{array}$ \\
\hline $\mathrm{Al}(\mathrm{III})$ & $10^{-5}$ & 101 & $\mathrm{Se}(\mathrm{IV})$ & $10^{-5}$ & 101 \\
\hline $\mathrm{Ba}(\mathrm{II})$ & $10^{-5}$ & 100 & $\mathrm{Te}(\mathrm{IV})$ & $10^{-5}$ & 101 \\
\hline $\mathrm{Ca}(\mathrm{II})$ & $10^{-3}$ & 102 & $\operatorname{Ti}(\mathrm{IV})$ & $10^{-5}$ & 92 \\
\hline $\mathrm{Cd}(\mathrm{II})$ & $10^{-5}$ & 100 & W(VI) & $10^{-5}$ & 95 \\
\hline $\mathrm{Co}$ (II) & $10^{-5}$ & 99 & $\mathrm{Zn}(\mathrm{II})$ & $10^{-5}$ & 101 \\
\hline $\mathrm{Cu}(\mathrm{II})$ & $10^{-5}$ & 88 & $\mathrm{~B}_{4} \mathrm{O}_{7}^{2-}$ & $10^{-3}$ & 103 \\
\hline $\mathrm{Ga}(\mathrm{III})$ & $10^{-5}$ & 100 & $\mathrm{CO}_{3}^{2-}$ & $10^{-3}$ & 108 \\
\hline Ge(IV) & $10^{-5}$ & 100 & $\mathrm{PO}_{4}^{3-}$ & $10^{-3}$ & 93 \\
\hline $\mathrm{K}(\mathrm{I})$ & $10^{-3}$ & 102 & $\mathrm{SO}_{4}^{2-}$ & $10^{-3}$ & 104 \\
\hline $\mathrm{Mg}(\mathrm{II})$ & $10^{-3}$ & 102 & Citric acid & $10^{-3}$ & —a \\
\hline $\mathrm{Mn}(\mathrm{II})$ & $10^{-5}$ & 100 & Cholesterol & $10^{-5}$ & 100 \\
\hline $\mathrm{Mo}(\mathrm{VI})$ & $10^{-5}$ & 90 & Glucose & $10^{-5}$ & 103 \\
\hline $\mathrm{Na}(\mathrm{I})$ & $10^{-3}$ & 102 & Uric acid & $10^{-5}$ & 99 \\
\hline $\mathrm{Ni}(\mathrm{II})$ & $10^{-5}$ & 102 & Albumin & $0.2 \mathrm{~g} \mathrm{ml}^{-1}$ & 101 \\
\hline $\mathrm{Pb}(\mathrm{II})$ & $10^{-5}$ & 101 & & $0.5 \mathrm{~g} \mathrm{ml}^{-1}$ & 85 \\
\hline
\end{tabular}

a. Negative peak.

Calibration graphs for glucose and uric acid were prepared under the optimum conditions; linear curves for each substrate were obtained in the range $1 \times 10^{-6}-6 \times 10^{-4} \mathrm{M}$. From the calibration graphs for hydrogen peroxide and the substrates, the conversions of glucose and uric acid to hydrogen peroxide by each oxidase reactor were $83 \%$ and $92 \%$, respectively. The reproducibility of the method was satisfactory with relative standard deviations of $1.3 \%$ and $1.2 \%$, respectively, for twenty determinations of each $1.0 \times 10^{-5} \mathrm{M}$ glucose and uric acid.

By using the FI system, as shown in Fig. 1, the determination of glucose and uric acid was performed by injecting standard serum samples which were diluted by a factor of 100 without deproteinization. The analytical results are shown in Table 2. The results for glucose and uric acid obtained by the present method coincided fairly well with those obtained by a standard method and certified values.

In conclusion, the reaction system of AA-DMA in the presence of iron(III) in place of peroxidase as a catalyst provides an inexpensive and sensitive FI method for the determination of hydrogen peroxide. The proposed method also permits the determination of biological substances, such as glucose and uric acid by using on-line enzyme reactors giving rise to hydrogen peroxide.

\section{References}

1. W. J. Cooper and R. G. Zika, Science, 1983, 220, 711.

2. Y. Zuo and J. Hoigne, Science, 1993, 260, 71.

3. B. C. Madsen and M. S. Kromis, Anal. Chem., 1984, 56, 2849.

4. C. Matsubara, K. Kudo, T. Kawashita, and K. Takamura, Anal. Chem., 1985, 57, 1107.

5. M. Akiba, S. Motomizu, and K. Toei, Bunseki Kagaku, 1987, 36, 561.

6. H. Afsar, R. Apak, and I. Tor, Analyst, 1990, 115, 99.

7. E. R. Kiranas, S. M. Tzouwara-Karayanni, and M. I. Karayannis, Analyst, 1993, 118, 727.

8. A. L. Lazrus, G. L. Kok, S. N. Gitlin, J. A. Lind, and S. E. McLaren, Anal. Chem., 1985, 57, 917.
Table 2 Determination of glucose and uric acid in standard sera

\begin{tabular}{ccccc}
\hline \multirow{2}{*}{ Analyte } & Serum & \multicolumn{3}{c}{ Concentration/mg dl $^{-1}$} \\
\cline { 3 - 5 } & & $\begin{array}{c}\text { Present } \\
\text { method }^{\mathrm{d}}\end{array}$ & $\begin{array}{c}\text { Reference } \\
\text { method }^{\mathrm{d}, \mathrm{e}}\end{array}$ & $\begin{array}{c}\text { Certified } \\
\text { value }\end{array}$ \\
\hline \multirow{2}{*}{ Glucose } & (I) $^{\mathrm{a}}$ & 72.0 & 67.0 & 74 \\
& (II) $^{\mathrm{b}}$ & 75.6 & 65.8 & $74-82$ \\
Uric acid & (III) $^{\mathrm{c}}$ & 92.0 & 79.1 & 91 \\
& (I) $^{\mathrm{a}}$ & 4.0 & 3.5 & 3.9 \\
& (II) $^{\mathrm{b}}$ & 5.1 & 4.9 & $4.7-6.7$ \\
& (III $^{\mathrm{c}}$ & 5.0 & 4.2 & 4.2 \\
\hline
\end{tabular}

a. Sera Chem, Clinical Chemistry Control Serum (Human) Level 1 issued by Iatron Laboratories, Inc.

b. Moni-Trol 1, Chemistry Control Serum issued by American Dade Co.

c. Q-PAK, Chemistry Control Serum 1 issued by Technicon Instruments Co.

d. Relative standard deviations $(n=3)$ were less than $2 \%$.

e. The values were obtained with kits for analyses of biological materials prepared by Iatron Laboratories, Inc.

9. H. Hwang and P. K. Dasgupta, Anal. Chem., 1986, 58, 1521.

10. J. Peinado, F. Toribio, and D. Perez-Bendito, Anal. Chem., 1986, 58, 1725.

11. Z. Genfa and P. K. Dasgupta, Anal. Chem., 1992, 64, 517.

12. T. Perez-Ruiz, C. Martinez-Lozano, V. Tomas, and O. Val, Food. Chem., 1993, 46, 301.

13. K. Hool and T. A. Nieman, Anal. Chem., 1988, 60, 834.

14. M. Stigbrand, E. Ponten, and K. Irgum, Anal. Chem., 1994, 66, 1766.

15. D. Price, P. J. Worsfold, and R. F. C. Mantoura, Anal. Chim. Acta, 1994, 298, 121.

16. T. Hasebe, E. Hasegawa, and T. Kawashima, Anal. Sci., 1996, 12,881 .

17. J. Lin, H. Arakawa, and M. Yamada, Anal. Chim. Acta, 1998, 371, 171.

18. H. Ohura, T. Imato, S. Yamasaki, and N. Ishibashi, Talanta, 1996, 43, 943.

19. M. Khayyami, G. Johansson, D. Kriz, B. Xie, P. Larsson, and B. Danielsson, Talanta, 1996, 43, 957.

20. W. R. Seitz, "Methods in Enzymology", LVII, 1978, Academic Press, New York, 445.

21. L. Gorton and L. Ogren, Anal. Chim. Acta, 1981, 130, 45.

22. H. A. Mottola, Anal. Chim. Acta, 1983, 145, 27.

23. P. J. Worsfold, Anal. Chim. Acta, 1983, 145, 117.

24. M. Masoom and A. Townshend, Anal. Chim. Acta, 1984, 166, 111.

25. M. Masoom and A. Townshend, Anal. Chim. Acta, 1985, 174, 293.

26. T. Yao, M. Sato, and T. Wasa, Nippon Kagaku Kaishi, 1985, 189.

27. D. Barham and P. Trinder, Analyst, 1972, 97, 142.

28. M. Sugiura and K. Hirano, Clin. Chim. Acta, 1977, 75, 387.

29. S. Nakano, C. Yamada, M. Sakai, and T. Kawashima, Anal. Sci., 1986, 2, 61.

30. S. Nakano, M. Tago, and T. Kawashima, Anal. Sci., 1989 , $5,69$.

31. S. Nakano, S. Kinoshita, M. Ikuta, and T. Kawashima, Anal. Sci., 1990, 6, 435

32. S. Nakano, M. Sakai. M. Kurachi, and T. Kawashima, Microchem. J., 1994, 49, 298. 